\title{
Purification and Properties of a Protease with Elastase Activity from Pseudomonas aeruginosa
}

\author{
By BENGT WRETLIND \\ Department of Clinical Microbiology, Karolinska Hospital, \\ $S$-I040 I Stockholm, Sweden \\ AND TORKEL WADSTRÖM* \\ Department of Bacteriology, National Bacteriological Laboratory, \\ S-I052I Stockholm, Sweden
}

(Received 9 June 1977)

\begin{abstract}
The isoelectric points of three proteases (I, II and III), separated from culture supernatants of Pseudomonas aeruginosa strain PAKS-I by isoelectric focusing, were 8.5, 6.6 and 4.5 respectively. Collagenase activity was not detected. More than $75 \%$ of the extracellular protease activity of this strain was due to protease II. This enzyme also possessed elastase activity. When purified by ammonium sulphate precipitation, isoelectric focusing and gel chromatography, protease II showed one band on disc electrophoresis and one band on conventional immunoelectrophoresis. The pH optimum, stability and effect of inhibitors and substrate concentration were examined. The molecular weight was $23000 \pm 5000$. Protease II was lethal for mice when injected intraperitoneally at a high dose (minimum lethal dose $0.1 \mathrm{mg}$ ). Dermonecrosis and subcutaneous haemorrhages were produced in new-born mice upon subcutaneous injection of ro $\mu \mathrm{g}$ protease II. A sensitive test for cytotoxicity showed no evidence of cytoplasmic membrane damage to HeLa cells or human diploid embryonic lung fibroblasts by protease II. Morphological changes similar to those produced by trypsin were found.
\end{abstract}

\section{INTRODUCTION}

Pseudomonas aeruginosa is a micro-organism with a low virulence for humans. However, it may cause severe infections in patients debilitated by burns, malignant tumours or chronic diseases (Young \& Armstrong, 1972; Flick \& Cluff, 1976). Strains of $P$. aeruginosa produce several extracellular proteins, some of which are believed to be virulence factors (Wretlind et al., 1973; Liu, 1974). Morihara (1964) showed that $P$. aeruginosa produced three proteases with different isoelectric points, substrate specificities and $\mathrm{pH}$ optima, and that one of these enzymes had elastase activity. Kreger \& Griffin (1974) separated three cornea-damaging proteases from the culture supernatant of a strain that was capable of producing keratitis in rabbits. These proteases seemed to correspond to those described by Morihara (1964).

One of the features of Pseudomonas septicaemia is the destruction of the arterial elastic lamina (Margaretten, Nakai \& Landing, 196I). There is evidence that this vascular lesion is precipitated by an elastolytic protease (elastase) (Mull \& Callahan, 1965). A correlation between the ability to produce protease in broth and virulence for mice was found for strains of $P$. aeruginosa (Muszyński, 1973). The above-mentioned investigations indicate a role

* Present address: Department of Bacteriology, Royal Veterinary College, Biomedicum, S-75I 23 Uppsala, Sweden. 
for the protease in the pathogenesis of Pseudomonas infections and that the proteases might be important factors contributing to the virulence of the organism.

The present study was undertaken to purify and characterize the protease with elastase activity on a scale large enough to allow studies on the physicochemical and biological properties of the enzyme, since conflicting reports on this subject have appeared (Liu, 1974).

\section{METHODS}

Bacterial strain and growth conditions. Pseudomonas aeruginosa strain PAKs-I was isolated from a human urine specimen at the Karolinska Hospital in 1970. The strain produced pyocyanin and was identified as Pseudomonas aeruginosa according to the methods described previously (Wretlind et al., 1973). This strain was the best producer of extracellular protease activity among 30 strains tested. It was stored in foetal calf serum at $-20^{\circ} \mathrm{C}$ and grown in: (i) brain heart infusion broth (BHI) supplemented with 50 mM-glucose; (ii) minimal medium of Davis \& Mingioli (1950) supplemented with tryptone $\left(5 \mathrm{gl}^{-1}\right)$, yeast extract $\left(2.5 \mathrm{~g} \mathrm{l}^{-1}\right)$, glucose (Io mM) and $\mathrm{CaCl}_{2}$ ( $\mathrm{mM}$ ) (MTYG); (iii) minimal medium supplemented with yeast extract $\left(2 \mathrm{~g} \mathrm{l}^{-1}\right)$, glucose (50 mM). and $\mathrm{CaCl}_{2}$ (I mM) (MYG); and (iv) MYG medium supplemented with Casamino acids ( $10 \mathrm{~g}^{-1}$ ) (MCYG). The different components were autoclaved separately.

Cultures were grown at $37^{\circ} \mathrm{C}$ for 14 to $16 \mathrm{~h}$ in $125 \mathrm{ml}$ medium in $\mathrm{I} l$ indented Erlenmeyer flasks (Arvidson, Holme \& Wadström, 197I) with rotary shaking ( $140 \mathrm{rev} . \mathrm{min}^{-1}$, rotation radius $25 \mathrm{~mm}$ ). Polypropylene glycol was used as an antifoaming agent. In later experiments, cultures were grown in a 31 fermenter (FL-103, Biotec, Stockholm, Sweden), as described by Arvidson et al. (1971), for $7 \mathrm{~h}$ at $37^{\circ} \mathrm{C}$. The impeller speed was $600 \mathrm{rev}$. $\mathrm{min}^{-1}$, aeration was at $\mathrm{I} 1 \mathrm{~min}^{-1}$, and $\mathrm{pH}$ was maintained at 7.0 by automatic addition of IM-HCl or I $\mathrm{M}-\mathrm{NaOH}$. Tributyl phosphate was used as an antifoaming agent. The inoculum was prepared by centrifuging (4000 $\mathrm{g}, 20 \mathrm{~min}) 300 \mathrm{ml}$ of an overnight culture in the same medium as in the fermenter and resuspending the bacteria in the fresh medium.

Assays. Protease activity was assayed according to Kunitz (1946/1947) using heat-denaturated casein as substrate. The extent of proteolysis was determined by reading the absorbance of perchloric acid-soluble degradation products at $280 \mathrm{~nm}$. The reaction mixture consisted of casein $\left(10 \mathrm{~g} \mathrm{l}^{-1}\right)$ in $0.05 \mathrm{M}$-sodium phosphate $\mathrm{pH} 7 \cdot 4$ supplemented with $\mathrm{CaCl}_{2}$ (I mM). The sample $(0.2 \mathrm{ml}$ ) was added to $4 \mathrm{ml}$ of the mixture, preincubated at $37^{\circ} \mathrm{C}$, and the reaction was terminated after $30 \mathrm{~min}$ by adding $3 \mathrm{ml} \mathrm{I} \mathrm{M-perchloric} \mathrm{acid.} \mathrm{The}$ precipitate was removed by centrifugation. A blank was prepared for each sample tested. One unit of activity was defined as an increase in $E_{280 \mathrm{~mm}}^{10 \mathrm{~mm}}$ of $\mathrm{I} \cdot 0$ in $30 \mathrm{~min}$ at $37^{\circ} \mathrm{C}$. The reaction was linear up to $E_{280 \mathrm{~mm}}^{10 \mathrm{~mm}}=0.5$.

Elastase activity was estimated by the elastin-congo red method of Sachar et al. (1955). Elastin-congo red was suspended in $0 . \mathrm{I} \mathrm{M}$-Tris/maleate buffer. One unit of elastase activity released soluble dye from $\mathrm{I} \mathrm{mg}$ elastin-congo red in $2 \mathrm{~h}$ at $35^{\circ} \mathrm{C}$, corresponding to $E_{496 \mathrm{~mm}}^{10 \mathrm{~mm}}=0.25$. A similar assay with elastin-orcein was used in a few experiments but was less sensitive.

Collagenase activity was estimated by the collagen disc assay described by Smyth \& Arbuthnott (1974).

Protein was determined according to Lowry et al. (195I) with bovine serum albumin as standard. The samples were dialysed against distilled water before analysis.

Isoelectric focusing. Electrofocusing was done in an LKB column of $440 \mathrm{ml}$ capacity according to Vesterberg et al. (1967). The focusing was run for $48 \mathrm{~h}$ and $\mathrm{Io} \mathrm{ml}$ fractions were collected. A pH gradient of 3 to Io was used consisting of Ampholine 3-5 (I ml), Ampholine 6-8 (2 ml) and Ampholine 3.5-10 (8.2 ml). A density gradient of glycerol [o to $60 \%(\mathrm{w} / \mathrm{v})$ ] was used in all experiments. Columns of $110 \mathrm{ml}$ capacity were used in a few experiments (for analytical purposes). A shallow gradient of $\mathrm{pH} 5$ to 8 was used for refocusing of protease II; it consisted of Ampholine 6-8 (0.8 ml) and Ampholine 5-7 (I.5 ml). A column of Iro ml capacity was used and $2 \mathrm{ml}$ fractions were collected.

Gel chromatography and molecular weight determination. Protease II was separated after isoelectric focusing by gel chromatography on columns of Biogel P-60 or Sephadex G-75 (I m $\times 25 \mathrm{~mm}$ ). The columns were calibrated at $4{ }^{\circ} \mathrm{C}$ with Dextran Blue 2000, cytochrome $c$, myoglobin, ovalbumin and haemoglobin (Wadström \& Hisatsune, 1970). The molecular weight was determined by the method of Andrews (1964).

Production of antisera. Antisera against culture supernatants were produced in rabbits. Culture supernatants were concentrated to one-tenth of their original volume by dialysis against polyethylene glycol and centrifuged at $100000 \mathrm{~g}$ at $4{ }^{\circ} \mathrm{C}$ for $4 \mathrm{~h}$. The pellet was discarded. The rabbits were injected four times at 3-week intervals with supernatants corresponding to 2 to $5 \mathrm{mg}$ protein mixed with Freund's complete adjuvant, followed by injection of the same amount of antigen intravenously I week before collection of blood.

Immunoelectrophoresis and disc electrophoresis. Immunoelectrophoresis was done according to Grabar \& Williams (1953). Disc electrophoresis on polyacrylamide gel was carried out as described by Wadström \& Möllby (1971) in a continuous Tris/glycine buffer at $\mathrm{pH} 8.5$. Samples containing $100 \mu \mathrm{g}$ protein were applied 
to each gel. Two gels were run with purified protease: one gel was stained with Coomassie blue, and the other was sliced longitudinally and applied to an agar plate containing $15 \%(\mathrm{v} / \mathrm{v})$ skimmed milk. Protease activity was detected as a clearing of the skimmed milk agar.

Purification of extracellular proteases. The culture supernatants ( 2 to $3 \mathrm{l})$ were centrifuged $(6000 \mathrm{~g}, 20 \mathrm{~min}$, $4^{\circ} \mathrm{C}$ ) and concentrated to approximately one-third of their original volume by dialysis against polyethylene glycol. Two volumes of saturated $\left(\mathrm{NH}_{4}\right)_{2} \mathrm{SO}_{4}\left(4^{\circ} \mathrm{C}, \mathrm{pH} 7\right)$ were added dropwise with constant stirring and left for $24 \mathrm{~h}$. The precipitate was collected by centrifugation, dissolved in $0.05 \mathrm{M}$-sodium phosphate buffer $\mathrm{pH} 7 \cdot 0$, dialysed against the same buffer overnight and then dialysed against distilled water. The pH was adjusted to 8.0 with $0.05 \mathrm{M}-\mathrm{NaOH}$. Negative adsorption was performed by adding $3 \mathrm{~g}$ diethylaminoethylSephadex (DEAE-Sephadex A-25) per litre of original culture supernatant (Wretlind, Möllby \& Wadström, 1971). The DEAE-Sephadex was removed by centrifugation and the supernatant was dialysed against $0.13 \mathrm{M}$-glycine, concentrated by dialysis against polyethylene glycol and subjected to isoelectric focusing. After electrofocusing, the peak fractions containing protease activity were pooled and chromatographed on Biogel P-60 or Sephadex G-75. The purified protease was concentrated Io-fold by ultrafiltration (Diaflo ultrafiltration membrane PMIo, Amicon, Lexington, Massachusetts, U.S.A.) and stored at $-60^{\circ} \mathrm{C}$.

Cytotoxicity tests. For determining membrane-damaging activity, a quantitative assay was used (Thelestam, Möllby \& Wadström, 1973). Human diploid embryonic lung fibroblasts and HeLa cells were incubated for $2 \mathrm{~h}$ in medium containing $\left[{ }^{3} \mathrm{H}\right]$ uridine $\left(\mathrm{I} \mu \mathrm{Ci} \mathrm{ml}{ }^{-1}, 20 \mathrm{Ci} \mathrm{mM}^{-1}\right)$. The cells were then exposed for $30 \mathrm{~min}$ to the protease diluted in Eagle medium to a final volume of $\mathrm{I} \mathrm{ml}$. The medium was removed and centrifuged, and the supernatant was transferred to a scintillation vial. Maximum release was measured after lysing the cells with $0.06 \mathrm{M}$-sodium borate buffer $\mathrm{pH} \mathrm{8.6.} \mathrm{The} \mathrm{samples} \mathrm{were} \mathrm{run} \mathrm{in} \mathrm{duplicate,} \mathrm{and} \mathrm{uninoculated} \mathrm{controls}$ were included.

Animal experiments. Female mice, strain NMRI (Anticimex, Stockholm, Sweden; 16 to $18 \mathrm{~g}$ ) were used for toxicity tests. The enzyme was injected intravenously or intraperitoneally. For a few experiments, NMRI mice (I to 2 days old), were injected subcutaneously with protease diluted in phosphate-buffered saline. The mice were observed for I week.

Chemicals. L-[(Toluene-4-sulphonamido)-2-phenyl ]ethyl chloromethyl ketone, $N$ - $\alpha$-toluene-4-sulphonyl-Llysine chloromethyl ketone hydrochloride, elastin-congo red, elastin-orcein, cytochrome $c$, myoglobin, ovalbumin, horse haemoglobin and Tris were obtained from Sigma; $N$ - $\alpha$-toluene-4-sulphonyl-L-arginine methyl ester hydrochloride from BDH; Dextran Blue 2000 from Pharmacia; agarose (Indubiose A 37) from L'Industrie Biologique Française, Gennevilliers, France; acrylamide and bis-acrylamide from Eastman Organic Chemicals; vitamin-free casein from Nutritional Biochemicals, Cleveland, Ohio, U.S.A; bovine serum albumin from AB Kabi, Stockholm, Sweden; polypropylene glycol P-200 from Dow Chemical Co., Midland, Michigan, U.S.A. and polyethylene glycol 20M (mol wt 20000) of technical grade from KEBO, Stockholm, Sweden.

\section{RESULTS}

\section{Influence of cultivation conditions}

Pseudomonas aeruginosa strain PAKs-I produced protease activity in all broth media tested. The yields during cultivation in shaking flasks in MTYG, MCYG and BHI plus glucose media were 20 to $30 \mathrm{u} . \mathrm{ml}^{-1}$. Cultivation in the fermenter yielded protease activities of 30 to $60 \mathrm{u}$. ml-1 in MCYG and MTYG media and 20 to $30 \mathrm{u}$. $\mathrm{ml}^{-1}$ in MYG medium. Collagenase activity was not detected in supernatants of cultures grown in $\mathrm{BHI}$ plus glucose medium.

\section{Isoelectric focusing of culture supernatants}

Culture supernatants from different media were subjected to isoelectric focusing. Three proteases were partially separated from MYG medium but only two proteases were found in MCYG medium (Fig. I). The peak fractions of the three proteases were at $\mathrm{pH} 8.5$ (protease I), $\mathrm{pH} 6 \cdot 0$ to $7 \cdot 2$ (protease II) and $\mathrm{pH}_{4.5}$ (protease III). Proteases I and II were detected in all media used, but protease III was not detected in MCYG medium and was sometimes absent in BHI plus glucose medium. Refocusing of protease II in a shallow $\mathrm{pH}$ gradient gave peak fractions of activity at $\mathrm{pH} 6 \cdot 2$ to 6.3 (Fig. 2). The isoelectric point of protease II could not be determined accurately, though based on 12 electrofocusing experiments a pI of $6.6 \pm 0.6$ was calculated. The isoelectric points of the other proteases $(8.5$ and $4 \cdot 5)$ were reproducible. 


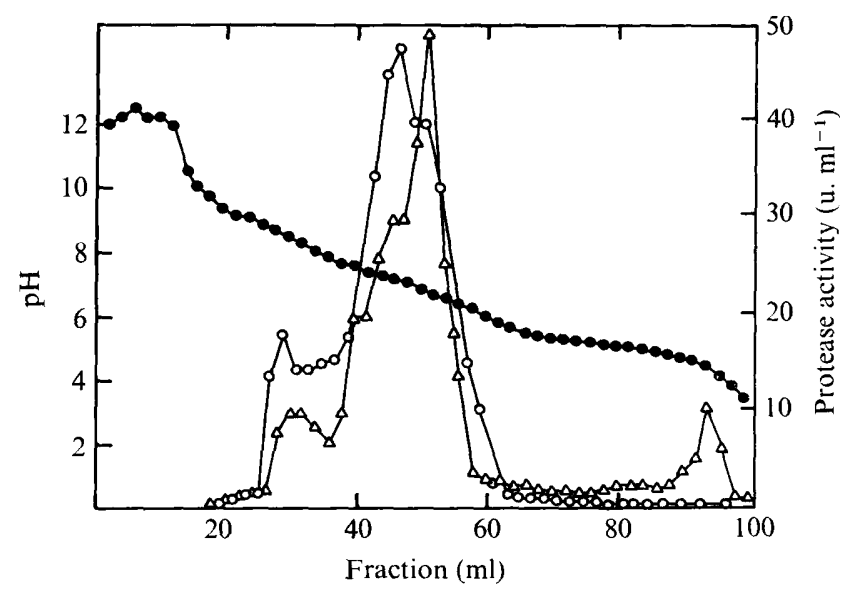

Fig. I. Separation by isolectric focusing, in a pH gradient of 3 to $10(0)$ at $4{ }^{\circ} \mathrm{C}$, of three proteases from crude culture supernatants of strain PAKs-I grown in MYG medium $(\triangle)$ and MCYG medium $(\bigcirc)$. The cultivations (in fermenters) and electrofocusing experiments were run in parallel.

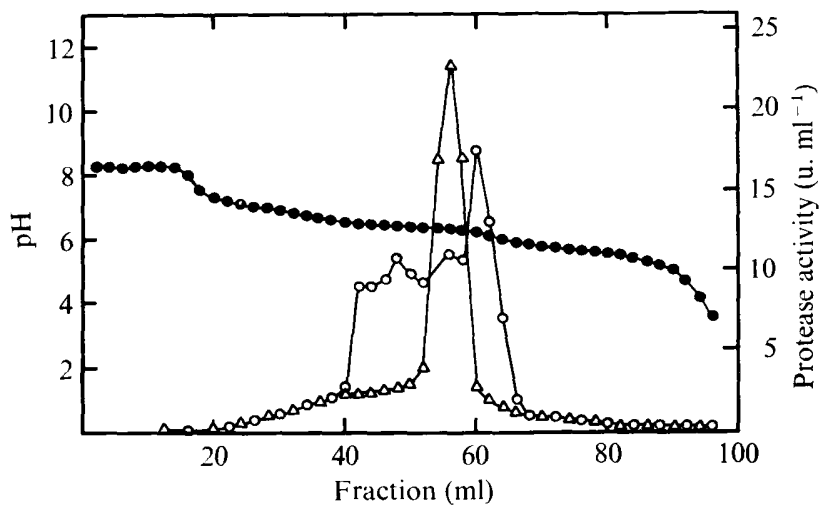

Fig. 2. Isolectric focusing, in a shallow pH gradient at $4{ }^{\circ} \mathrm{C}$, of protease II (pI 6.6 0.6 ) from the experiment shown in Fig. I. Symbols as in Fig. I.

\section{Purification of protease II}

For purification of proteases, MTYG medium was chosen since all three proteases were produced in this medium and the protease activity was higher than in MYG medium. After growth in MTYG medium in a fermenter, protease II was purified from the culture supernatant by $\left(\mathrm{NH}_{4}\right)_{2} \mathrm{SO}_{4}$ precipitation, negative adsorption with DEAE-Sephadex, isoelectric focusing and gel chromatography (Table I). Based on electrofocusing experiments, 75 to $90 \%$ of the total protease activity of the culture supernatant was calculated to be due to protease II. The final yield was thus 3 to $4 \%$ after correction for the activities of proteases I and III in the supernatant. Similar results were obtained after growth of cultures in MCYG, MYG and BHI plus glucose media. The molecular weight of protease II as determined by gel chromatography on Sephadex G-75 or Biogel P-60 was $23000 \pm 5000$ (five experiments; Fig. 3). Disc electrophoresis of the purified protease showed one band in gels containing $7.5 \%(\mathrm{w} / \mathrm{v})$ polyacrylamide (Fig. 4). However, in gels containing $5 \%$ and I0 \% polyacrylamide two faint extra bands were visible. The zymogram on agar containing skimmed milk showed that the main band was associated with protease activity. Immunoelectrophoresis gave one line of precipitate. The protease did not migrate during electrophoresis. 
Table I. Purification of protease II from a culture supernatant of Pseudomonas aeruginosa

The culture supernatant was from strain PAKS-I grown in a tryptone-containing broth (MTYG) at $37^{\circ} \mathrm{C}$ in a 31 fermenter.

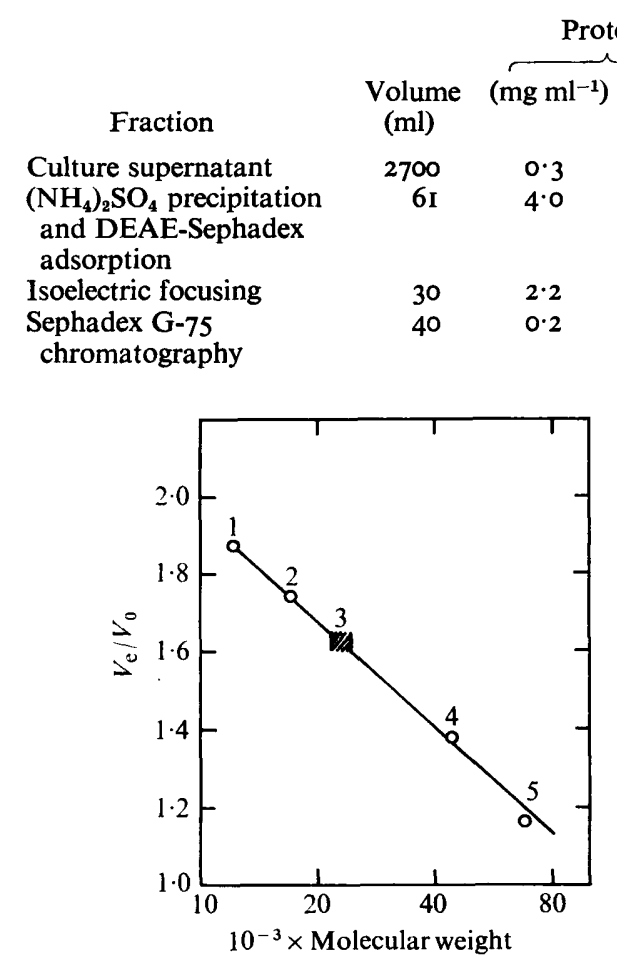

Fig. 3

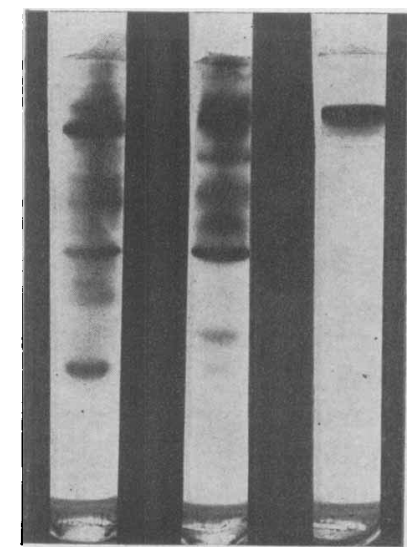

Fig. 4

Fig. 3. Determination of the molecular weight of protease II by chromatography on Sephadex G-75: I, cytochrome $c: 2$, myoglobin; 3, pseudomonas protease II: 4, ovalbumin; 5 , haemoglobin.

Fig. 4. Analytical polyacrylamide gel electrophoresis of protease II. From left to right: culture supernatant; enzyme after isoelectric focusing; purified protease after chromatography on Sephadex G-75. The gels contained $7 \cdot 5 \%$ polyacrylamide.

\section{Properties of purified protease}

With casein as substrate, protease II had a pH optimum at 8.0 (Fig. 5) in both sodium phosphate and Tris/HCl buffers. Elastase activity of protease II was I4 times higher in Tris/maleate than in sodium phosphate buffer, and the $\mathrm{pH}$ optimum was also affected by the buffer, being 6.5 in Tris/maleate and 8.0 in phosphate buffer (Fig. 5).

The rate of hydrolysis of casein was determined in phosphate buffer containing I mM$\mathrm{CaCl}_{2}$. The action of protease II followed Michaelis-Menten kinetics when determined by the method of Lineweaver \& Burk (1934). A $K_{\mathrm{m}}$ value of $\mathrm{I} \cdot 5 \mathrm{~g}$ casein $1^{-1}$ and a $V_{\max }$ value of $0.4 \Delta E_{280 \mathrm{~mm}}^{10 \mathrm{~mm}}(30 \mathrm{~min})^{-1} \mu \mathrm{g}^{-1}\left(\mathrm{pH}_{7} \cdot 4\right)$ based on a specific activity of $350 \mathrm{u}$. $\mathrm{mg}^{-1}$ were calculated from these data.

Of the different ions and potential inhibitors of caseinolytic activity tested (Table 2), heavy metal ions, dithiothreitol and EDTA were inhibitory.

Purified protease II was rapidly degraded at $4{ }^{\circ} \mathrm{C}$ with an estimated half-life of 3 to 5 days. The enzyme activity was stable for more than a year at $-60{ }^{\circ} \mathrm{C}$, but lost 30 to $50 \%$ of its activity after 4 months at $-20{ }^{\circ} \mathrm{C}$. 


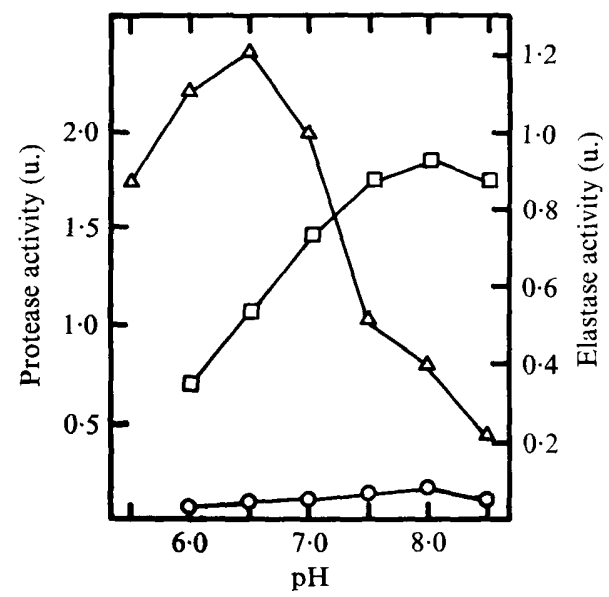

Fig. 5. Effect of pH on protease (caseinolytic) and elastase activity of protease II. Protease activity in phosphate buffer $(\square)$; elastase activity in Tris/maleate buffer $(\triangle)$; elastase activity in phosphate buffer (O).*All buffers were supplemented with $\mathrm{I} \mathrm{mM}-\mathrm{CaCl}_{2}$. To each tube was added $0.5 \mu \mathrm{g}$ protease for the caseinolytic assay and $8 \mu \mathrm{g}$ protease for the elastase assay.

\section{Toxicity studies}

The minimum lethal dose in mice for protease II was $0 \cdot \mathrm{I} \mathrm{mg}$ after intravenous or intraperitoneal injection. Subcutaneous injection of $\mathrm{I} / \mathrm{g}$ into newborn mice caused local dermonecrosis and subcutaneous haemorrhages. The lesions healed after I week but no hair growth appeared in the damaged area.

Cytotoxicity tests showed no evidence of membrane damage as indicated by lack of leakage of $\left[{ }^{3} \mathrm{H}\right]$ uridine when HeLa cells or human embryonic lung fibroblasts were treated with Io to $100 \mu \mathrm{g}$ purified protease II ml ${ }^{-1}$. However, morphological changes were seen with rounding of the cells, similar to those produced by trypsin (Thelestam et al., 1973).

\section{DISCUSSION}

Morihara (1964) separated three proteases from $P$. aeruginosa by ion exchange chromatography which seem to correspond to those obtained in this study as judged by similarities in $\mathrm{pH}$ optima, isoelectric points and, in the case of protease II, elastase activity. However, Morihara et al. (1965) estimated the molecular weight of fraction II (corresponding to protease II in this study) to be 39500 by determining the sedimentation coefficient by ultracentrifugation. The molecular weight we found for protease II (23000) agrees with the results of Kreger \& Griffin (1974) and Scharmann \& Balke (1974). The reason for this discrepancy is not known but differences in the strains of $P$. aeruginosa used, in the methods for purifying the enzymes and in the methods for determining molecular weight are probably important.

The isoelectric points of the various proteases do, however, agree. Although the pI of protease II of PAKS-I varied between $6 \cdot 0$ and $7 \cdot 2$ when culture supernatants were subjected to isoelectric focusing, these differences did not depend on the media used. The lack of reproducibility is therefore possibly due to post-synthetic modification such as autodigestion of the enzyme. Similar results have been described for several bacterial enzymes and toxins, e.g. staphylococcal proteins (Arbuthnott, McNiven \& Smyth, 1975). Suss et al. (I969) reported the existence of two distinct elastases in strains of $P$. aeruginosa which showed complete immunological identity and similar properties except for isoelectric points, indicating the existence of two molecular forms with different charge properties.

Scharmann \& Balke (1974) found only one protease in culture supernatants of their 
Table 2. Effect of metal salts, reducing and chelating agents and protease inhibitors on the activity of purified protease II

Protease activity was assayed according to Kunitz (1946/1947) using casein as substrate in $0.05 \mathrm{M}$-Tris/ $\mathrm{HCl} \mathrm{pH} \mathrm{7.4}$. The enzyme was pre-incubated with the various agents for $\mathrm{I} 6 \mathrm{~h}$ at $4{ }^{\circ} \mathrm{C}$. Results are expressed as a percentage of the control activity which was I 6 u.'ml-1.

\begin{tabular}{|c|c|c|}
\hline Agent tested & $\begin{array}{l}\text { Concn } \\
(\mathrm{mm})\end{array}$ & $\begin{array}{c}\text { Protease } \\
\text { activity } \\
(\%)\end{array}$ \\
\hline \multirow{3}{*}{$\begin{array}{l}\text { None (control) } \\
\mathrm{CaCl}_{2}\end{array}$} & 一 & 100 \\
\hline & I & 100 \\
\hline & 10 & 100 \\
\hline \multirow[t]{2}{*}{$\mathrm{CdCl}_{2}$} & I & 30 \\
\hline & IO & 22 \\
\hline \multirow[t]{2}{*}{$\mathrm{CuCl}_{2}$} & I & II \\
\hline & 10 & I \\
\hline \multirow[t]{2}{*}{$\mathrm{MgCl}_{2}$} & I & 89 \\
\hline & 10 & 61 \\
\hline \multirow{3}{*}{$\begin{array}{l}\mathrm{MnCl}_{2} \\
\mathrm{ZnCl}_{2}\end{array}$} & I & 44 \\
\hline & I & 42 \\
\hline & IO & 8 \\
\hline \multirow[t]{2}{*}{$\mathrm{HgCl}_{2}$} & I & 2 \\
\hline & IO & 0 \\
\hline \multirow[t]{2}{*}{$\mathrm{CoCl}_{2}$} & 1 & I I I \\
\hline & IO & 85 \\
\hline \multirow{2}{*}{$\begin{array}{l}\text { Sodium } \\
\text { cacodylate }\end{array}$} & I & 100 \\
\hline & 10 & 100 \\
\hline \multirow[t]{2}{*}{ EDTA } & I & $3 I$ \\
\hline & IO & 4 \\
\hline \multirow[t]{2}{*}{ Dithiothreitol } & I & 57 \\
\hline & IO & 53 \\
\hline $\begin{array}{l}N \text { - } \alpha \text {-Toluene-4- } \\
\text { sulphonyl-L-arginine } \\
\text { methylester.HCl }\end{array}$ & 10 & 100 \\
\hline $\begin{array}{l}\text { L-[(Toluene-4- } \\
\text { sulphonamido)-2- } \\
\text { phenyl]ethyl } \\
\text { chloromethyl ketone }\end{array}$ & I0 & 100 \\
\hline $\begin{array}{l}N \text { - } \alpha \text {-Toluene-4- } \\
\text { sulphonyl-L- } \\
\text { lysine chloromethyl } \\
\text { ketone. } \mathrm{HCl}\end{array}$ & IO & 100 \\
\hline
\end{tabular}

strain of $P$. aeruginosa which contrasts with our findings. Their result, however, may be due to using complex media containing amino acids as we, like Morihara (I964), found that protease fraction III (corresponding to protease III) was not produced in such media. Alternatively, different strains may produce different protease profiles. Indeed, proteases with properties different from the enzymes described in this paper have been characterized from other isolates of $P$. aeruginosa. Schoellman \& Fisher (1966) found a collagenase active against a synthetic substrate and Carrick \& Berk (1975) described another, probably different, collagenolytic enzyme which was not identical to any of the enzymes produced by strain PAKS-I.

The toxicity of our purified protease II is consistent with previous reports (Meinke et al., I970; Kawaharajo et al., I975 b). The minimum lethal dose for mice (0. I to $0.5 \mathrm{mg}$ depending on the route of inoculation) indicates a low toxicity compared with bacterial toxins, such as exotoxin A from $P$. aeruginosa with an $\mathrm{LD}_{50}$ for mice of $140 \mathrm{ng}$ (Callahan, 1976). As protease II is inhibited by $\alpha_{2}$-macroglobulin in serum (Hochstrasser, Theopold \& Brandl, I973), it probably cannot contribute to the ability of the micro-organism to produce lethal 
infections. Studies on the virulence of protease-deficient mutants of strain PAKS-I for mice again indicate that the role of these enzymes in bacteraemic infections has been overestimated (B. Wretlind and T. Kronevi, unpublished observations). However, the dermonecrotic and cornea-damaging effects are produced by a few micrograms of purified protease (Kreger \& Griffin, 1974; Kawaharajo et al., 1974, 1975a), which suggests a role in localized infections where serum protease inhibitors may not be present in sufficient amounts.

Although Botzenhart \& Ebel (1973) and Pflüger, Scharmann \& Blobel (1975) found a cytotoxic effect of protease from $P$. aeruginosa, we failed to detect a membrane-damaging effect in HeLa cells and fibroblasts, using a sensitive method, beyond that elicited by trypsin (Blumberg \& Robbins, I975). The tissue damage caused by pseudomonas protease II probably depends more on the effect on elastin or the ground substance of connective tissue and cornea than on cytotoxic effects in infected patients or animals.

We are indebted to Dr Cyril J. Smyth for valuable suggestions and revision of the manuscript, and to Dr Monika Thelestam for cytotoxicity tests. The expert technical assistance of Ms Kristina Karlsson, Ms Marianne Kjellgren and Ms Kristina Jäderberg is gratefully acknowledged. This work was supported by a grant from the Research Institute of the Swedish National Defence.

\section{REFERENCES}

ANDREWS, P. (I964). Estimation of the molecular weights of proteins by Sephadex gel-filtration. Biochemical Journal 91, 222-233.

Arbuthnott, J. P., McNiven, A. C. \& Smyth, C. J. (1975). Multiple forms of bacterial toxins in preparative isoelectric focusing. In Isoelectric Focusing, pp. 2 I 2-239. Edited by J. P. Arbuthnott and J. A. Beeley. London: Butterworths.

Arvidson, S., Holme, T. \& Wadström, T. (I97I). Influence of cultivation conditions on the production of extracellular proteins by Staphylococcus aureus. Acta pathologica et microbiologica scandinavica B79, 399-405.

Blumberg, P. M. \& Robins, P. W. (1975). Relation of protease action on the cell surface to growth control and adhesion. In Proteases and Biological Control, pp. 945-956. Edited by E. Reich, D. B. Rifkind and E. Shaw. Cold Spring Harbor, New York: Cold Spring Harbor Laboratory.

Botzenhart, K. \& Ebel, E. A. (1973). Cytotoxic activity of Pseudomonas aeruginosa with regard to lecithinase, lipase, hemolysin, and surface activity. Zentralblatt für Bakteriologie, Parasitenkunde, Infektionskrankheiten und Hygiene (Abteilung I Originale A) 225, 387-397.

Callahan, L. T. (1976). Pseudomonas aeruginosa exotoxin: purification by preparative polyacrylamide gel electrophoresis and the development of a highly specific antitoxin serum. Infection and Immunity $\mathrm{x}$, 55-6I.

CARrick, JR, L. \& Berk, R. S. (1975). Purification and partial characterization of a collagenolytic enzyme from Pseudomonas aeruginosa. Biochimica et biophysica acta 39r, 422-434.

Davis, B. D. \& Mingioli, E. S. (1950). Mutants of Escherichia coli requiring methionine or vitamin $B_{12}$. Journal of Bacteriology 6o, 17-28.

Flick, M. R. \& Cluff, L. E. (1976). Pseudomonas bacteremia. Review of 108 cases. American Journal of Medicine 60, 501-508.
Grabar, P. \& Williams, C. A. (I953). Méthode permettant l'étude conjugée des propiétés électrophoretiques et immunochimiques d'un mélange de protéines. Application au sérum sanguin. Biochimica et biophysica acta 10, 193-194.

Hochstrasser, K., Theopold, H. M. \& Brandl, $O$. (1973). Zur Hemmbarkeit der Proteinasen aus Pseudomonas aeruginosa durch $\alpha_{2}$-Makroglobulin. Hoppe-Seyler's Zeitschrift für physiologische Chemie 354, IOI3-10I6.

Kawaharajo, K., Abe, E., Homma, J. Y., Kawano, M., Gotoh, E., Tanaka, N. \& Morihara, K. (1974). Corneal ulcers caused by protease and elastase from Pseudomonas aeruginosa. Japanese Journal of Experimental Medicine 44, 435-442.

Kawaharajo, K., Homma, J. Y., Aoyama, Y., OKADA, K. \& MorIHARA, K. (I975a). Effects of protease and elastase from Pseudomonas aeruginosa on skin. Japanese Journal of Experimental Medicine 45, 79-88.

Kawaharajo, K., Homma, J. Y., Aoyama, Y. \& Morihara, K. (1975b). In vivo studies on protease and elastase from Pseudomonas aeruginosa. Japanese Journal of Experimental Medicine 45, 89-100.

Kreger, A. S. \& Griffin, O. K. (1974). Physiochemical fractionation of extracellular corneadamaging proteases of Pseudomonas aeruginosa. Infection and Immunity 9, 828-834.

Kunitz, M. (I946/1947). Crystalline soybean trypsin inhibitor. II. General properties. Journal of General Physiology 30, 29I-310.

LiNeweAVER, H. \& BURK, D. (I934). The determination of enzyme dissociation constants. Journal of the American Chemical Society 56, 658-666.

Liu, P. V. (1974). Extracellular toxins from Pseudomonas aeruginosa. Journal of Infectious Diseases r30, Supplement, S94-S99.

Lowry, O. H., Rosebrough, N. J., FarR, A. L. \& RANDALl, R. J. (I95I). Protein measurement with 
the Folin phenol reagent. Journal of Biological Chemistry 193, 265-275.

Margaretten, W., Nakai, H. \& Landing, B. H. (I96I). Significance of selective vasculitis and the 'bone-marrow' syndrome in Pseudomonas septicemia. New England Journal of Medicine 265, 773-776.

Meinke, G., Barum, J., Rosenberg, B. \& Berk, R. S. ( I970). In vivo studies with the partially purified protease (elastase) from Pseudomonas aeruginosa. Infection and Immunity 2, 58 I-589.

Morihara, K. (1964). Production of elastase and proteinase by Pseudomonas aeruginosa. Journal of Bacteriology 88, 745-757.

Morihara, K., Tsuzuki, H., OKa, T., InOUe, H. \& Eвata, M. (1965). Pseudomonas aeruginosa elastase. Isolation, crystallization, and preliminary characterization. Journal of Biological Chemistry 240, 3295-3304.

Mull, J. D. \& Callahan, W. S. (1965). The role of the elastase of Pseudomonas aeruginosa in experimental infection. Experimental and Molecular Pathology 4, 567-575.

MUSZYŃSKI, Z. (1973). Enzymatic and toxinogenic activity of culture filtrates of high and low virulent strains of Pseudomonas aeruginosa on mice. Pathologia et microbiologia 39, I35-147.

Pflüger, R., ScharmanN, W. \& Blobel, $\mathrm{H}$. (I975). Toxicity of culture supernatants from Pseudomonas aeruginosa. Zentralblatt für Bak teriologie, Parasitenkunde, Infektionskrankheiten und Hygiene (Abteilung IOriginale A) 233, 236-244.

Sachar, L. A., Winter, K. K., Sicher, N. \& FranKEL, S. (1955). Photometric method for estimation of elastase activity. Proceedings of the Society for Experimental Biology and Medicine 90, 323-326.

SCharmanN, W. \& BalKe, E. (I974). Untersuchungen über eine Protease (Elastase) von Pseudomonas aeruginosa. I. Bildung und Reinigung der Protease. Hoppe-Seyler's Zeitschrift für physiologische Chemie 355, 443-450̀.

SchoellmanN, G. \& Fisher, JR, F. (1966). A collagenase from Pseudomonas aeruginosa. Biochimica et biophysica acta 122, 557-559.
Smyth, C. J. \& Arbuthnott, J. P. (I974). Properties of Clostridium perfringens (Welchii) type A $\alpha$-toxin (phospolipase C) purified by electrofocusing. Journal of Medical Microbiology 7, 4I-66.

Suss, R. H., Fenton, II, J. W., Muraschi, T. F. \& Miller, K. D. (I969). Two distinct elastases from different strains of Pseudomonas aeruginosa. Biochimica et biophysica acta 191, I79-181.

Thelestam, M., Möllby, R. \& Wadström, T. (1973). Effects of staphylococcal alpha-, beta-, delta-, and gamma-hemolysins on human diploid fibroblasts and HeLa cells: evaluation of a new quantitative assay for measuring cell damage. Infection and Immunity 8, 938-946.

VesterberG, O., WADSTRÖM, T., VesterberG, K. Svensson, H. \& Malmgren, B. (1967). Studies on extracellular proteins from Staphylococcus aureus. I. Separation and characterization of enzymes and toxins by isoelectric focusing. Biochimica et biophysica acta $\mathbf{1 3 3}, 435-445$.

WAdSTRöm, T. \& Hisatsune, K. (1970). Bacteriolytic enzymes from Staphylococcus aureus. Purification of an endo- $\beta$ - $N$-acetylglucosaminidase. Biochemical Journal 120, 725-734.

WAdSTröm, T. \& MöllbY, R. (I97I). Studies on extracellular proteins from Staphylococcus aureus. VI. Production and purification of $\beta$-haemolysin in large scale. Biochimica et biophysica acta $\mathbf{2 4 2}$, 288-307.

Wretlind, B., HedÉn, L., SJöBerG, L. \& WADSTRÖM, T. (1973). Production of enzymes and toxins by hospital strains of Pseudomonas aeruginosa in relation to serotype and phage-typing pattern. Journal of Medical Microbiology 6, 9I-IOO.

WRETLIND, B., Möllby, R. \& WADSTRöM, T. (I97I). Separation of two hemolysins from Aeromonas hydrophila by isoelectric focusing. Infection and Immunity 4, 503-505.

Young, L. S. \& Armstrong, D. (1972). Pseudomonas aeruginosa infections. CRC Critical Reviews in Clinical Laboratory Sciences 3, 291-347. 